\title{
Magnetostratigraphy of Late Neogene Glacial, Interglacial, and Preglacial sediments in the Saskatoon and Regina areas, Saskatchewan, Canada
}

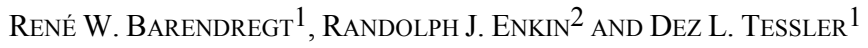 \\ 1 Department of Geography, University of Lethbridge, 4401 University Drive, Lethbridge, \\ Alberta, T1K 3M4, Canada (barendregt@uleth.ca) \\ 2 Geological Survey of Canada, Pacific, Sidney, British Columbia, V8L 4B2, Canada \\ (renkin@nrcan.gc.ca)
}

Received: March 5, 2011; Accepted (in original form): April 5, 2011

\begin{abstract}
Two new records of glacial stratigraphy obtained from borecores collected in southcentral Saskatchewan are compared to previously published records from Wellsch Valley and Swift Current Creek in southern Saskatchewan. The comparisons are based on magnetostratigraphy and tephrochronology, and describe preglacial, glacial, and interglacial deposits. The new stratigraphy is compared to the composite global marine oxygen isotope record.

Although the ages and extents of late Pleistocene continental glaciations are relatively well constrained, they are less well defined for the middle and early Pleistocene. Data presented here highlight recent studies carried out from borecores and outcrops of extensive pre-Illinoian (pre-Saalian) glacial deposits. Based on this new data, at least seven Laurentide (continental) glaciations are recognized in Saskatchewan, and these records are the most extensive to date in the Northern Interior Plains of Canada.

The magnetostratigraphic records from the Sutherland Overpass and Wascana Creek sites provide the first evidence of reversely magnetized glacial deposits in the Canadian Prairies. These deposits can be assigned to the latest Matuyama (MIS 20) and indicate that Laurentide (continental) glaciations did not impact southern Saskatchewan until the late Early Pleistocene.
\end{abstract}

Keywords: magnetostratigraphy, glacial history, western Canada, till, BrunhesMatuyama

\section{INTRODUCTION}

This study forms part of a broader examination of glacial deposits in western Canada (Fig. 1) to better define the ages and extent of Laurentide glaciations during the Pleistocene (Barendregt and Duk-Rodkin, 2011; Barendregt, 2011). With improved age control, glacial deposits can be assigned to the appropriate cold peaks of the global marine oxygen isotope record (Fig. 2). 


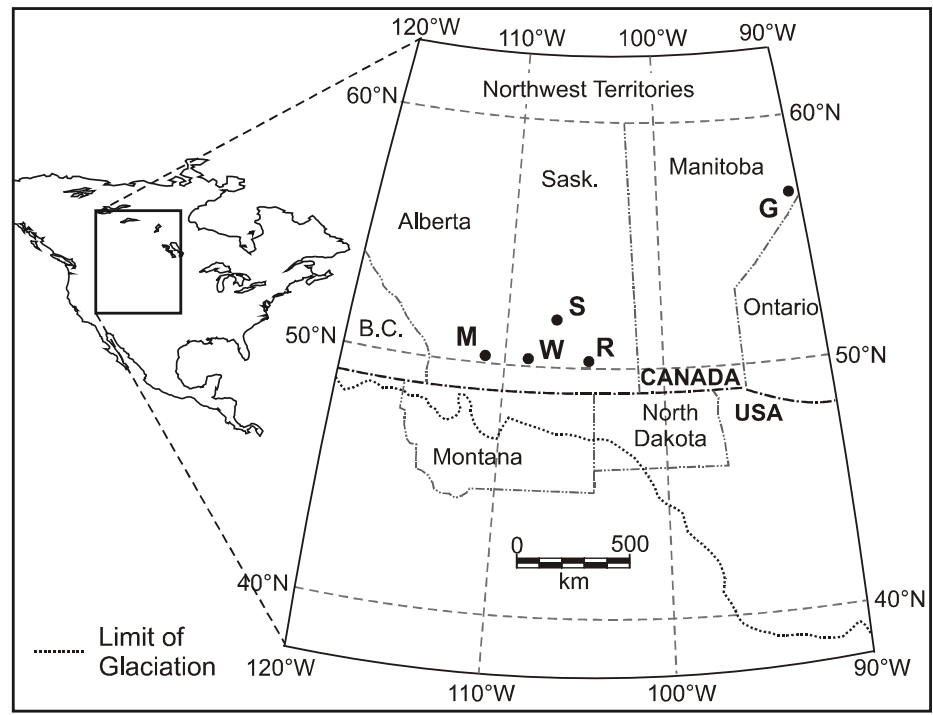

Fig. 1. Location map of Saskatchewan study sites: Sutherland borecore sites at Saskatoon (S), Wascana Creek borecores and outcrops near Regina (R), Wellsch Valley borecores and outcrops (W). Extensive sequences of glacial deposits also occur at Medicine Hat, Alberta (M) and Gillam, Manitoba (G).

While multiple till sheets blanket much of the Canadian Prairies, few opportunities exist for the dating of these deposits. Most fall outside the range of ${ }^{14} \mathrm{C}$ dating, and few outcrops expose the older Pleistocene record. Paleomagnetic measurements of borecore samples collected in buried valleys provide an opportunity for correlation of sediments with the global polarity time scale. Where till magnetostratigraphy can be combined with other geochronological controls such as tephrochronology and/or paleontology, glacial events can be placed in a reliable time-stratigraphic framework. Here we report the paleomagnetic record of sediments from two sites that contain an extensive Pleistocene stratigraphy. The Sutherland Overpass site in Saskatoon (Fig. 1) provides an important reference section for the Pleistocene history of south-central Saskatchewan (Christiansen, 1968, 1992), while the Wascana Creek site in southern Saskatchewan displays most of the stratigraphic units seen in the Saskatoon area, and contains the Middle Pleistocene Wascana Creek Tephra (Westgate et al., 1977; Lanphere et al., 2002).

Fig. 2 (Facing Page). Geomagnetic polarity time scale (Cande and Kent, 1995) for LR04 benthic $\delta^{18} \mathrm{O}$ palaeotemperature profile (Lisiecki and Raymo, 2005). Black/white intervals represent normal/reversed polarity. Marine Isotope Stages (MIS) are labelled on LR04 (even numbers represent glacials; odd numbers interglacials). MIS numbering scheme follows Ruddiman et al. (1986, 1989) and Raymo et al. $(1989,1992)$ from present to MIS 104, and Shackleton et al. (1995) for the Gauss Chron. Arrow marks Holocene mean $\delta^{18} \mathrm{O}$ (Raymo, 1992). Pleistocene as defined in Gibbard et al. (2010). 
Magnetostratigraphy of Late Neogene Glacial, Interglacial, and Preglacial sediments in Canada

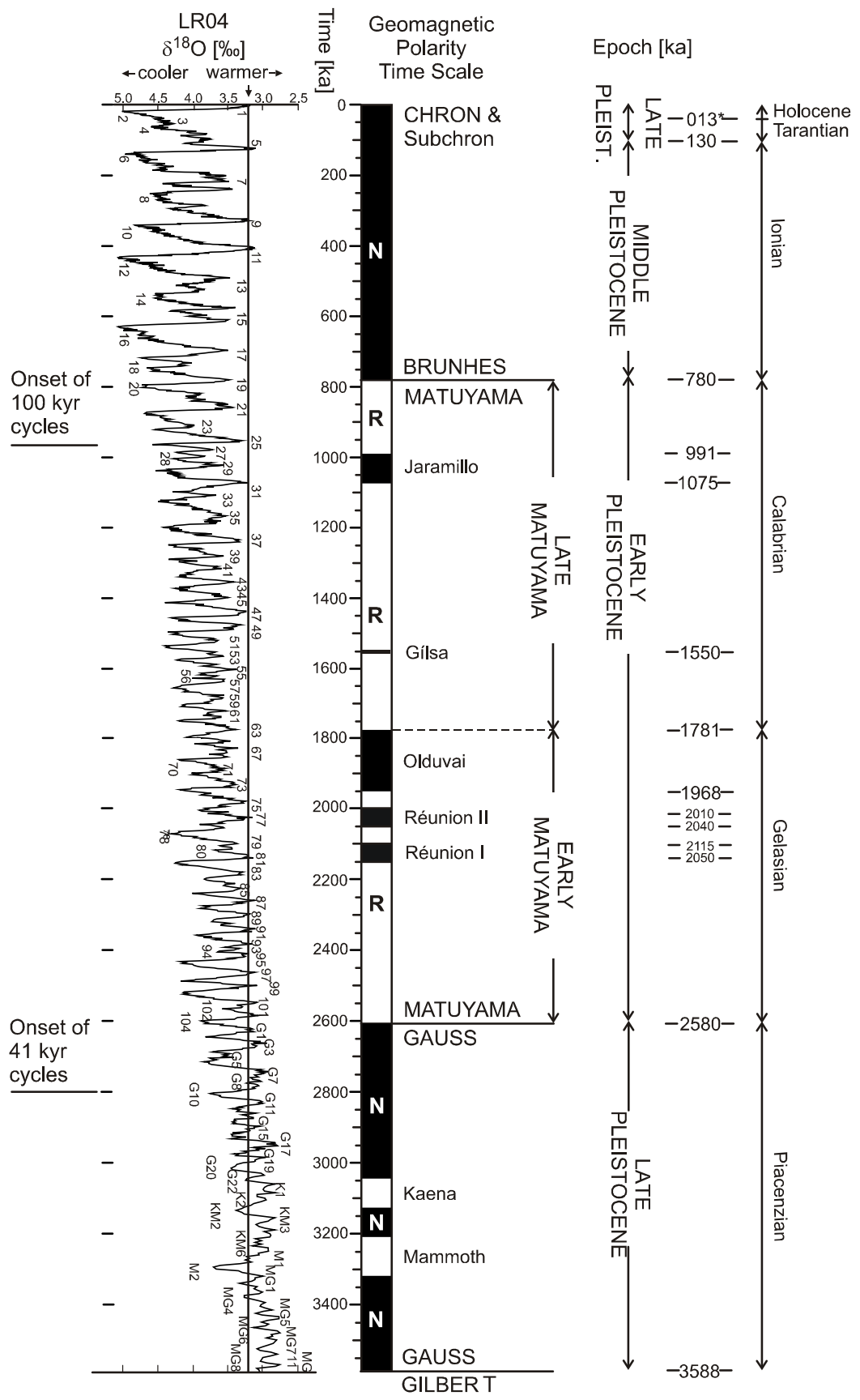




\section{R.W. Barendregt et al.}

\section{STUDY SITES}

\subsection{Sutherland Overpass Borecore, Saskatoon, S a s k t chewan}

Recent borecores drilled at the Sutherland Overpass in the city of Saskatoon, Saskatchewan (Fig. 1) were collected near reference sites where previous studies had established an extensive record of Pleistocene tills. Some of these tills were assumed to be pre-Illinoian in age, and this study was carried out, in part, to establish whether any of the tills were reversely magnetized, and thus older than $0.78 \mathrm{Ma}$ (Fig. 2). The Sutherland borecore includes the tills of the Mennon, Dundurn, and Warman Formations, which are collectively referred to as the Sutherland Group (Christiansen, 1968, 1992). The Sutherland Group (Fig. 3) includes all sediments between the preglacial Empress Group and the Saskatoon Group (a stratigraphic sequence of Illinoian and younger deposits, including the Floral and Battleford Formations) and is defined from outcrops along the North Saskatchwan River valley as well as borecores collected nearby.

\subsection{Wascana Creek Site, near Regina, Saskatchewan}

The Wascana Creek site is located 19 km northwest of Regina, Saskatchewan (Fig. 1) and was recently re-examined to obtain a magnetic polarity record from sediments above and below the Wascana Creek Tephra. Only the upper two-thirds of the Pleistocene stratigraphic sequence at the Wascana Creek site is accessible from outcrops along the west bank of the creek. The lower third of the stratigraphic sequence is described from several borecores drilled near the edge of the valley. Outcrop and borecore records (Fig. 3) reveal four tills (assigned from oldest to youngest, to the Mennon Fm, upper unit of the Dundurn Fm, Warman Fm, and Battleford Fm). These tills can be correlated with reference sections to the north (Christiansen, 1968, 1992) near Saskatoon, Saskatchewan (Fig. 3), and to the southwest (Barendregt et al., 1991, 1998) near Wellsch Valley, Saskatchewan (Figs. 1 and 4). The Wascana Creek Tephra (0.639 $\pm 0.002 \mathrm{Ma}$; Lanphere et al., 2002) occurs within glacio-lacustrine sediments assigned to the Dundurn Fm, and is overlain by the Warman Fm (till). It is also known as the Lava Creek B Tephra in the USA, a Pearlette-type ash from the Yellowstone area, found at a number of localities in the American Midwest. At the Wascana Creek site the tephra clearly dates the upper unit of the Dundurn Fm (till) to marine oxygen isotope stage (MIS) 16 (Figs. 2 and 3), and points to the antiquity of the underlying tills (lower unit of the Dundurn Fm, and the Mennon Fm). If the latter two tills represent separate glaciations, then the Mennon Fm would be expected to fall in MIS 20 or older and should be reversely magnetized.

\subsection{Paleomagnetic Sampling Procedures}

In the borehole sampling strategy used in this study (Fig. 5), two holes were drilled at each site, both to bedrock. The first borehole provided a log of the stratigraphic units present, and the thickness of each unit, and from this record sampling depths were selected. All bit cuttings were collected, washed and dried for laboratory analysis (Fig. 5e). In the second borehole, samples were collected from each of the major units present. Sample collection was carried out as follows: (1) a rotary bit was used to drill 

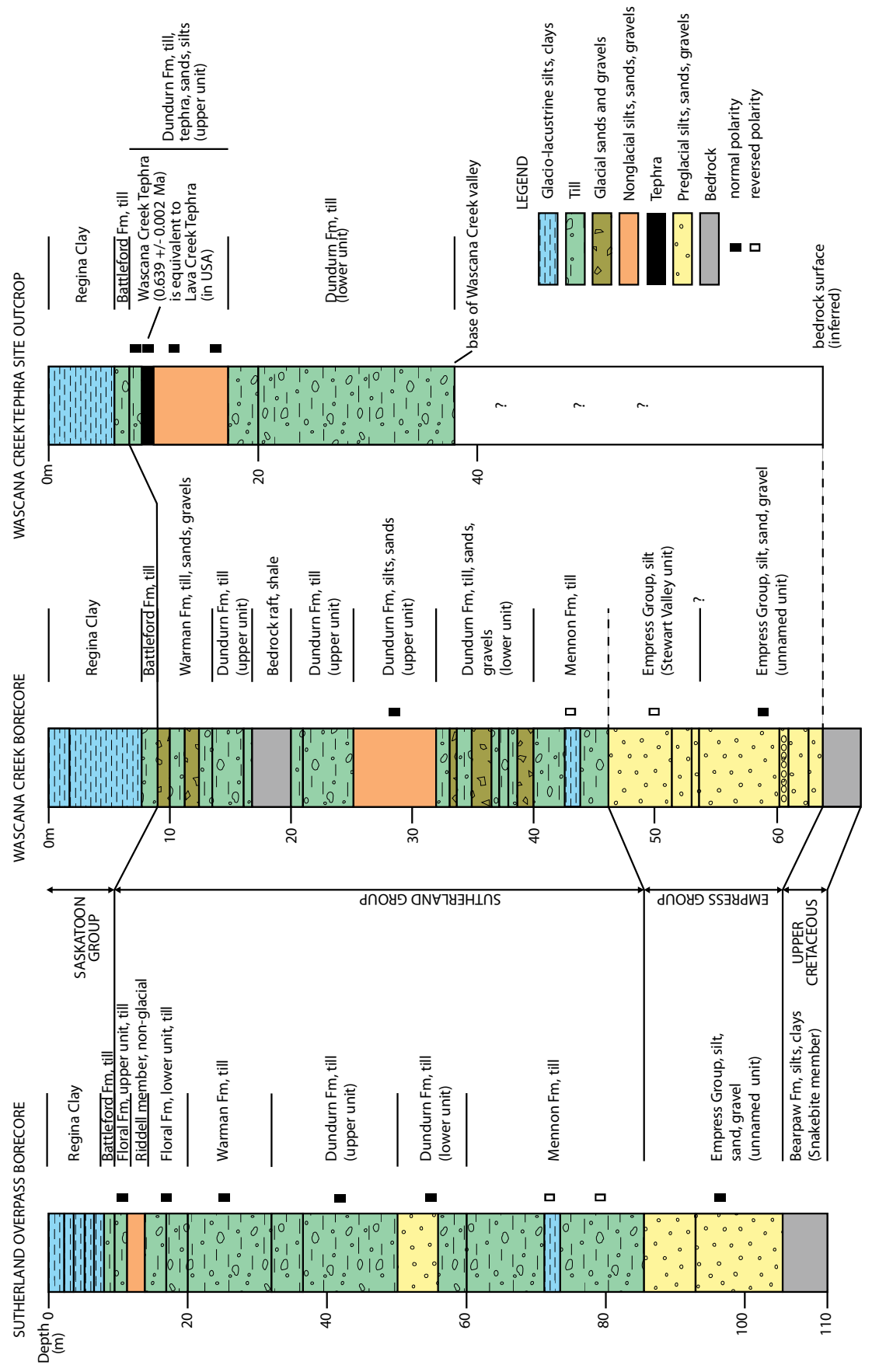

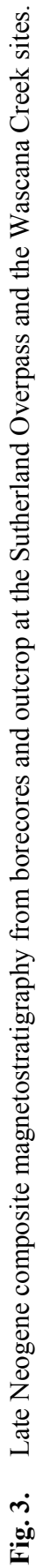




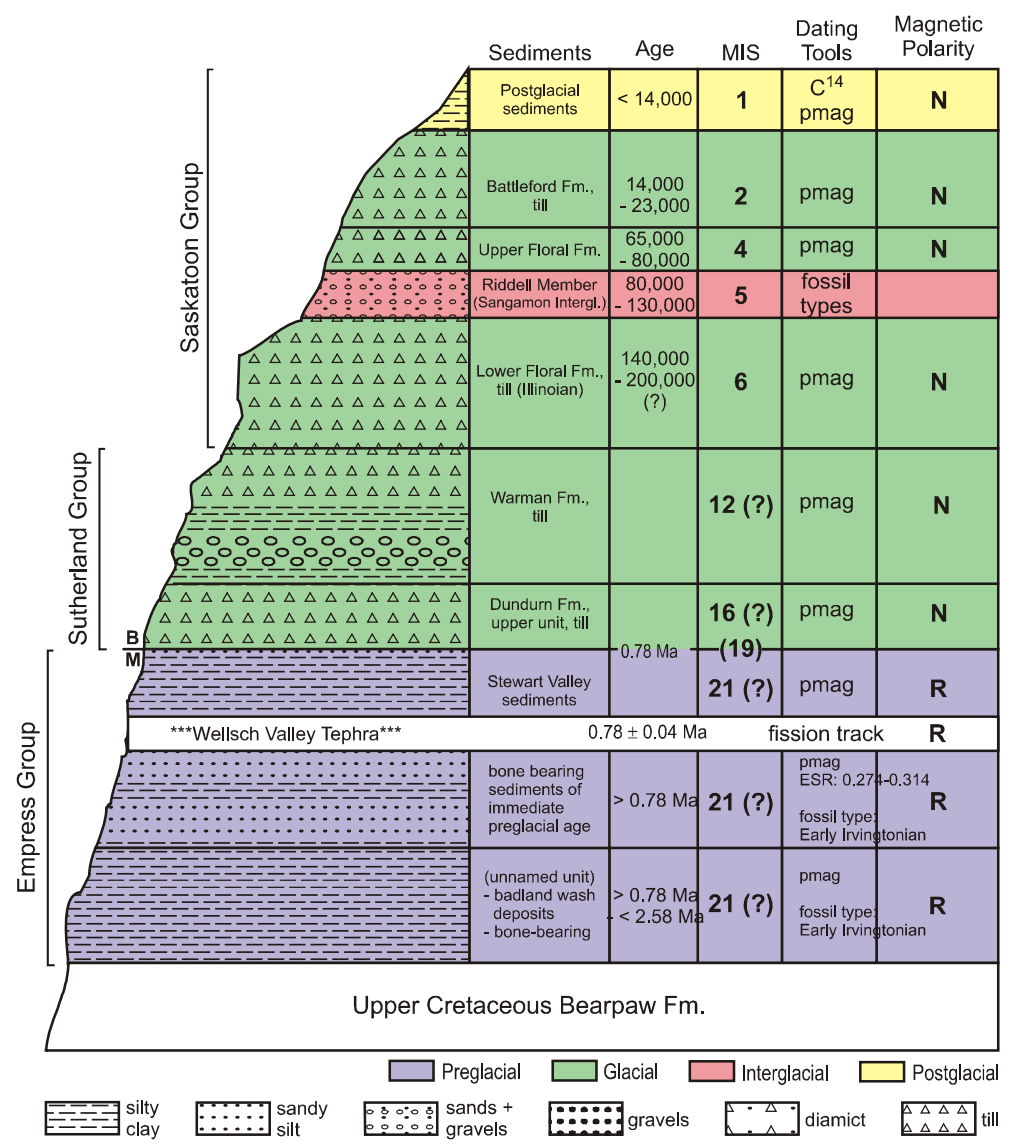

Fig. 4. Late Neogene composite stratigraphy from borecores and outcrops at the Wellsch Valley sites, near Swift Current, Saskatchewan.

down to a selected depth; (2) the drill stem was raised, the bit was removed, and a heavywalled steel tube $(0.5 \mathrm{~m}$ length, $10 \mathrm{~cm}$ diameter, and bearing an orientation mark) was attached; (3) the drill stem and attached steel tube were lowered to the bottom of the hole, and the tube was pushed into the sediment (without drill stem rotation); (4) the drill stem and tube were raised to the surface (again without rotation); (5) sediment was extracted from the oriented tube, and the orientation mark was transferred to the sediment core; (6) this process was repeated until all selected units were sampled. Fully oriented cores were split and sampled at $10 \mathrm{~cm}$ intervals by inserting polycarbonate plastic cylinders of standard paleomagnetic rock specimen dimensions ( $2.5 \mathrm{~cm}$ diameter, $2.2 \mathrm{~cm}$ length) using a hydraulic press. Small amounts of core rotation sometimes occurred during the extrusion process. In two cases, where tills were stony, considerable rotation occurred. This is evident from the anomalous declination values for the Upper and Lower Floral Fm tills in the Sutherland borecore (Table 1). Inclination values, and therefore the determination of polarity are unaffected by rotation. 

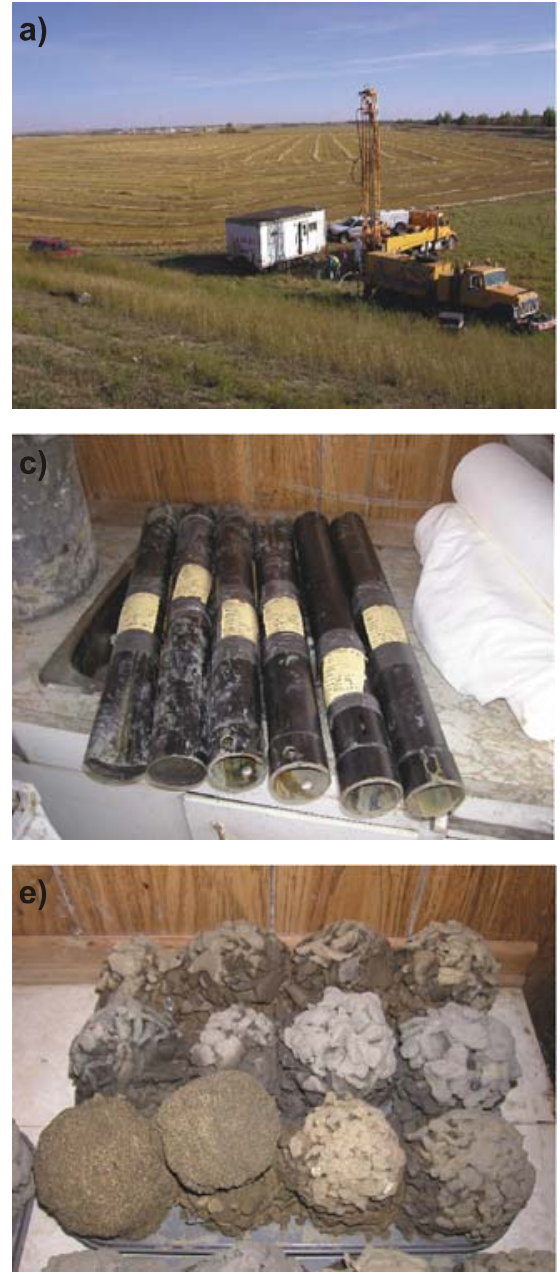
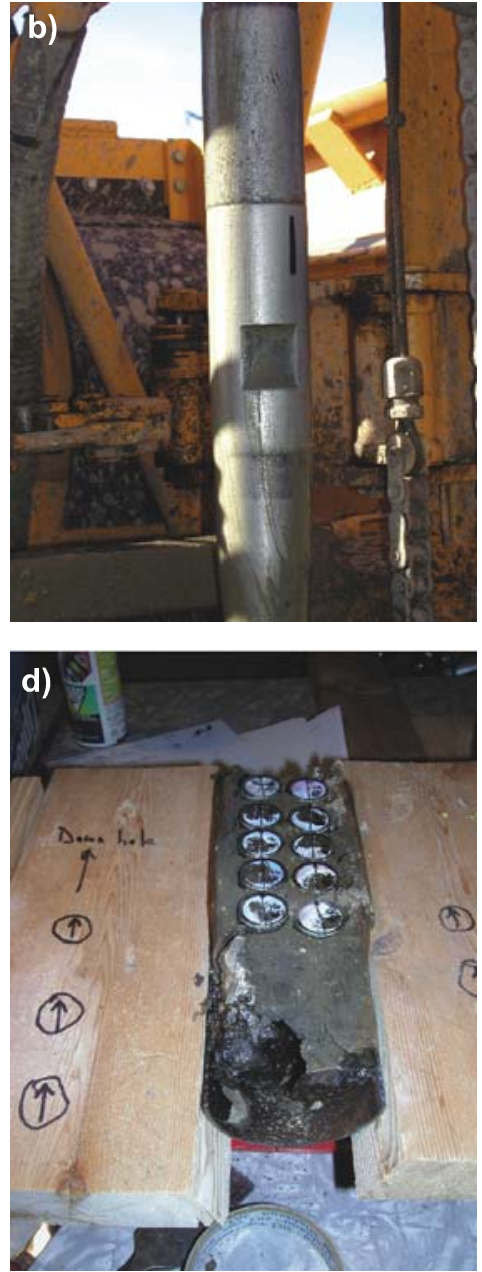

Fig. 5. a) Truck mounted drilling rig used in borecore sampling; b) orientation mark on drill stem; c) steel tubes used in sample collection; d) subsampling of split core; e) bit cuttings collected from exploratory borehole.

Paleomagnetic results from the first borecore drilled at the Sutherland Overpass (Barendregt et al., 2007; Barendregt, 2010) yielded incoherent magnetizations for several of the till units. A second core collected from a nearby site yielded better results. Incoherent magnetization occurs for a number of reasons, but in the case of glacial tills the most likely reasons include insufficient water content in till slurries at the time of deposition, preventing clay-sized ferro-magnetic minerals from becoming oriented in the earth's field, or post-depositional disturbance of sediments. 


\section{R.W. Barendregt et al.}

Outcrop sampling was possible only at the Wascana Creek site. This was done by horizontally inserting poly-carbonate plastic cylinders into cleaned vertical faces excavated along the valley wall. Cylinders have a sharpened and tapered cutting edge, and internal raised splines on the base and side which serve as orientation marks and prevent movement of sediment inside the cylinder. Insertion azimuths of cylinders were measured using a magnetic compass. Samples were generally selected from sorted, fine-grained sediments. Where fine-grained sediments were not present, samples were taken from

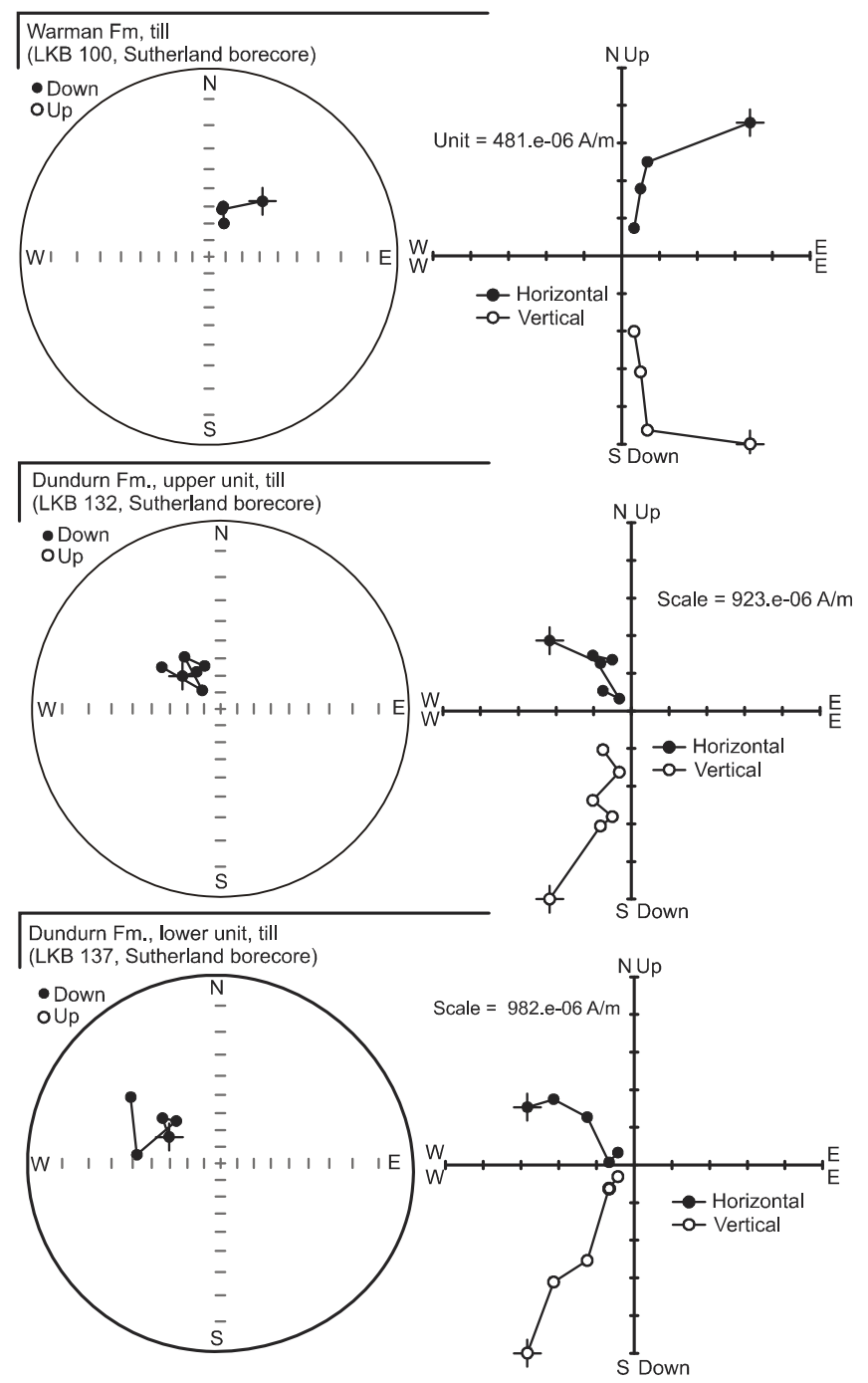

Fig. 6. a) Orthogonal plots of stable, single component magnetizations for samples from stratigraphic units listed in Table 1. Sutherland borecore units. 
sorted coarser deposits containing a sufficiently fine-grained matrix, or from interstitial fine-grained pockets within tills. As far as was possible, sediments containing pebbles were avoided. In this manner, it was possible to sample all lithologic units at the Wascana Creek outcrop. In the case of waterlaid sediments, samples were collected in a vertical string, typically $10 \mathrm{~cm}$ apart, while in tills, which represent a "snapshot" in time, extensive vertical sampling from bottom to top is unnecessary.

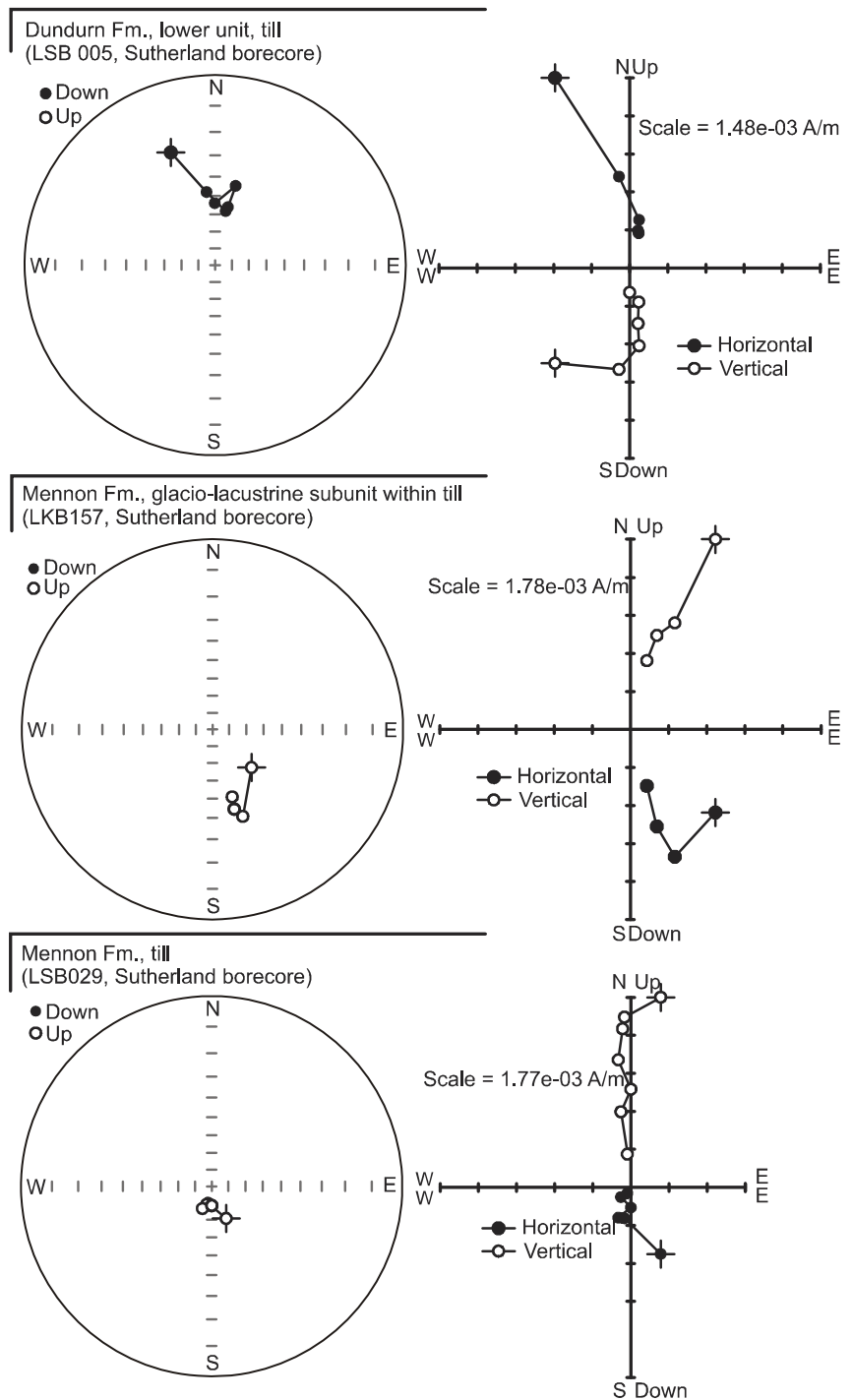

Fig. 6. b) Symbols as in Fig. 6a. 


\section{R.W. Barendregt et al.}

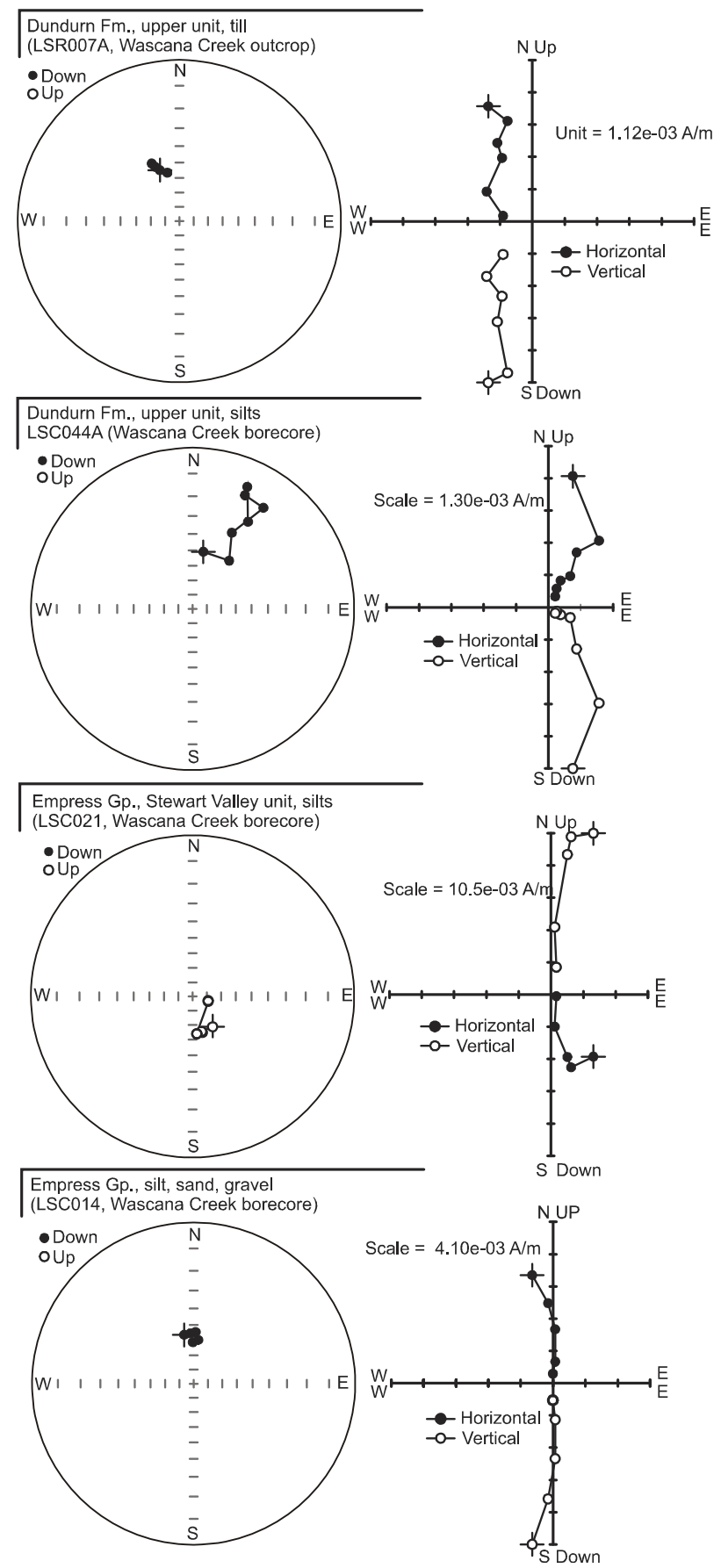

Fig. 6. c) Symbols as in Fig 6a. Plots are for Wascana Creek borecore and outcrop units. 


\section{PALEOMAGNETIC MEASUREMENTS}

Paleomagnetic remanence measurements were made at the Geological Survey of Canada - Pacific, Sidney, British Columbia, using an AGICO JR5-A spinner magnetometer. Stepwise alternating field demagnetization in peak fields up to $100 \mathrm{mT}$ was carried out using a Schonstedt GSD-5 with a three-axis tumbler. Samples were typically demagnetized at 10,20,30,40,60, and often $80 \mathrm{mT}$ steps. Sample remanence directions were determined by principle component analysis (PCA), see Kirschvink (1980).

\section{PALEOMAGNETIC RESULTS}

\subsection{General Observations}

Normal and reversed magnetizations occur at both sampling sites (Table 1), and polarities can be assigned to all of the sampled units. In comparison with other glacial lithologies studied, the magnetic stability of these collections was relatively low, accounting for the lower proportion (108/340 or 32\%) of samples that gave satisfactory results. (In our experience, $50 \%$ of samples are often rejected in paleomagnetic analyses of glacial tills because of weak or unstable magnetizations, or incoherent remanence directions held by randomly oriented sand or pebbles within the sample; Barendregt et al., 1991, 1998.)

In this study, the majority of the samples $(80 \%)$ were collected from glacial tills, and the remainder from fluvial and lacustrine deposits. Most samples revealed magnetizations typical of magnetite. Median destructive fields for magnetite-bearing sediments typically ranged from 30 to $60 \mathrm{mT}$. The demagnetization data for coherent samples almost always revealed a single high coercivity component, so that directions were fit using principle component analysis of lines that were forced through the origin of orthogonal plots. Fig. 6 provides examples of well-behaved normal- and reverse-polarity demagnetization curves. A plot of sample directions, by unit, for each of the study sites is provided in Fig. 7a,b. For about $35 \%$ of the samples it was not possible to isolate a primary normal or reverse polarity remanence.

\subsection{Paleomagnetic Directions}

In Table 1, Fisher-averaged directions of each unit are listed and polarities defined. Stereographic plots of unit means and their $95 \%$ confidence intervals for both sites are given in Fig. 8a, and plots of mean normal, mean reversed, and overall mean are provided in Fig. 8b. In most paleomagnetic studies of glacial deposits, and also in this study, the mean directions show relatively high dispersion $\left(\alpha_{95}\right)$. This presumably reflects variable quality acquisition of detrital remanent magnetization, as well as depositional and postdepositional disturbances.

The inclination mean $\left(61^{\circ}\right)$ is somewhat shallower than the expected geocentric axial dipole (GAD) inclination of $68^{\circ}$ for the sampling latitudes $\left(\sim 52^{\circ} \mathrm{N}\right)$. 


\subsection{Magnetostratigraphy}

Sediments from the Sutherland Overpass borecores (Figs. 3 and 8a) record a reversely magnetized suite of preglacial sediments at their base, referred to as the Empress Group. These are directly overlain by the reversely magnetized till of the Mennon Fm, which in turn is overlain by normally magnetized deposits of the Dundurn, Warman, Floral and Battleford Fms.

Sediments from the Wascana Creek site (Figs. 3 and 8a) record a normal and reversely magnetized suite of preglacial sediments at the base of the borecore, and like those found at the base of the Sutherland borecores, are assigned to the Empress Group. These are overlain by reversely magnetized till and glacio-lacustrine sediments of the Mennon Fm, which are overlain (in turn) by normally magnetized deposits of the Dundurn, Warman and Battleford Fms.
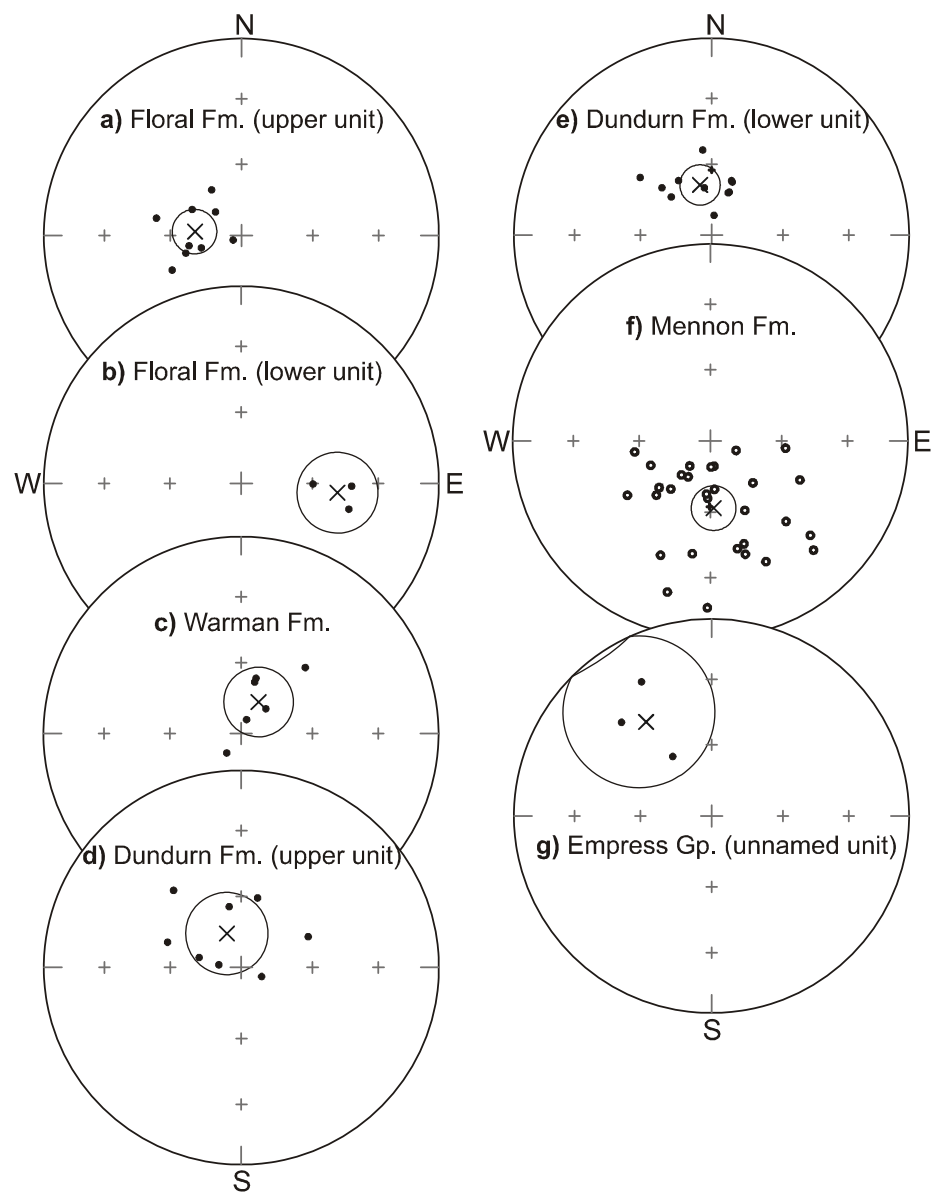

Fig. 7. a) Plots of PCA-fitted sample directions for Sutherland borecore. Mean directions $(x)$ and circles of confidence $\left(\alpha_{95}\right)$ of units are also plotted, and are listed in Table 1. 


\subsubsection{Preglacial Sediments}

Based on data from the base of the Sutherland and Wascana Creek borecores, the preglacial deposits record at least two polarities, suggesting that the Empress Gp sediments at these sites span considerable time, perhaps as much as $\sim 2.0 \mathrm{Ma}$ $(\sim 0.83-\sim 3.0 \mathrm{Ma})$. At the Wellsch Valley site (Fig. 1) and nearby Swift Current Creek borecore site (Barendregt et al., 1991, 1998) the Pleistocene sequence is also underlain by a similar suite of preglacial sediments, all of which are reversely magnetized (Figs. 4 and 9). The Wellsch Valley Tephra $(0.78 \pm 0.04 \mathrm{Ma})$, and fossils of early Irvingtonian age (Churcher and Stalker, unpublished results) occur near the upper limit of the preglacial sediments at the Wellsch Valley site, suggesting that deposition of these deposits continued until the first continental (Laurentide) ice sheet (MIS 20) occupied the area, immediately prior to the Matuyama/Brunhes reversal (0.78 Ma).

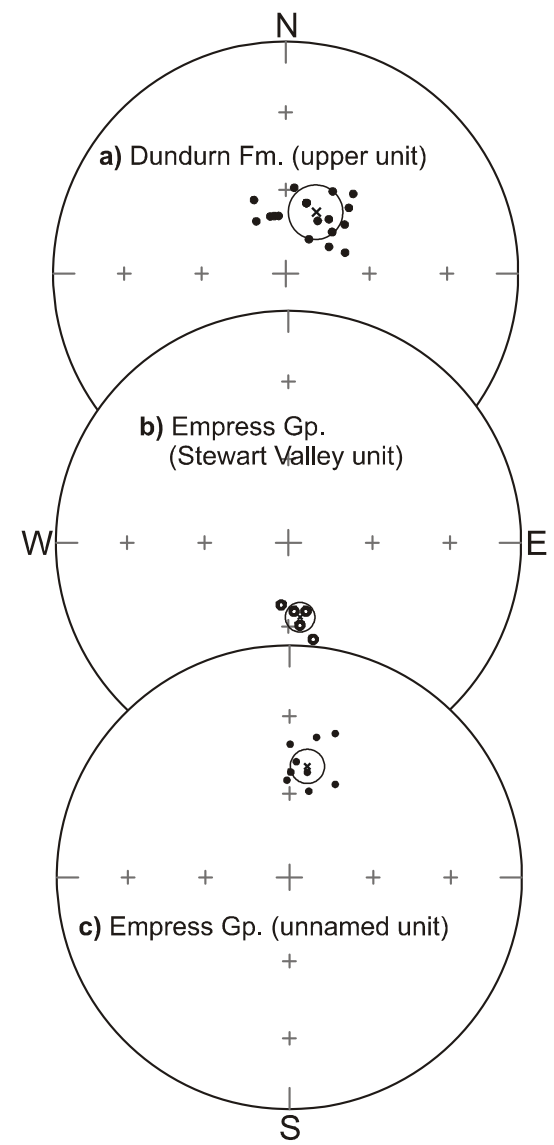

Fig. 7. b) The same as in Fig. 7a, but for Wascana Creek outcrop and borecore units. 


\section{R.W. Barendregt et al.}

Table 1. Summary of paleomagnetic directions. $N t$ - number of sites sampled within each unit; $N s$ - total number of specimens from each unit; $D$ and $I$ - declination and inclination of the mean direction; $k$ - precision parameter; $\alpha_{95}$ - circle of confidence $(P=0.05)$; $\mathrm{P}$ - polarity. The mean inclinaton expected for a geocentric axial dipole at this sampling latitude is $68^{\circ}$. Present earth's field direction at sampling locality: $D=11^{\circ}$ (easterly), $I=75^{\circ} .{ }^{*}$ Declination values for Upper and Lower Floral Fm probably affected by core rotation during extraction process.

\begin{tabular}{|c|c|c|c|c|c|c|c|c|c|}
\hline Unit & Lithology & $N t$ & $N s$ & $D$ & $I$ & $k$ & $\alpha_{95}$ & $\mathrm{P}$ & Chron \\
\hline \multicolumn{10}{|c|}{ Sutherland Borecore } \\
\hline Upper Floral Fm & till & 1 & & *263 & 63 & 13 & 16 & $\mathrm{~N}$ & Brunhes \\
\hline Lower Floral Fm & till & 1 & 3 & $* 96$ & 38 & 44 & 19 & $\mathrm{~N}$ & Brunhes \\
\hline Warman Fm & till & 2 & 6 & 29 & 69 & 13 & 19 & $\mathrm{~N}$ & Brunhes \\
\hline Dundurn Fm (upper unit) & till & 2 & 8 & 337 & 69 & 7 & 23 & $\mathrm{~N}$ & Brunhes \\
\hline Dundurn Fm (lower unit) & till & 5 & 16 & 336 & 57 & 12 & 15 & $\mathrm{~N}$ & Brunhes \\
\hline Mennon Fm & $\begin{array}{l}\text { till \& glac.-lac. } \\
\text { silts }\end{array}$ & 6 & 30 & 177 & -52 & 6 & 12 & $\mathrm{R}$ & Matuyama \\
\hline Empress Gp (unnamed unit) & silt, sand, gravel & 1 & 3 & 325 & 31 & 24 & 26 & $\mathrm{~N}$ & Gauss \\
\hline \multicolumn{10}{|c|}{ Wascana Creek Outcrop and Borecore } \\
\hline Dundurn Fm (upper unit) outcrop & $\begin{array}{l}\text { till \& glac.-lac. } \\
\text { silts }\end{array}$ & 2 & 11 & 1 & 56 & 26 & 9 & $\mathrm{~N}$ & Brunhes \\
\hline Dundurn Fm (upper unit) outcrop & $\begin{array}{l}\text { tephra-Wascana } \\
\text { Ck }\end{array}$ & 1 & 1 & 287 & 75 & $\mathrm{n} / \mathrm{a}$ & $\mathrm{n} / \mathrm{a}$ & $\mathrm{N}$ & Brunhes \\
\hline Mennon Fm borecore & till & 2 & 7 & 169 & -31 & 4 & 38 & $\mathrm{R}$ & Matuyama \\
\hline $\begin{array}{l}\text { Empress Gp (Stewart Valley } \\
\text { unit) borecore }\end{array}$ & clays and silts & 2 & 6 & 171 & -63 & 174 & 5 & $\mathrm{R}$ & Matuyama \\
\hline $\begin{array}{l}\text { Empress Gp (unnamed unit) } \\
\text { borecore }\end{array}$ & silts and sands & 2 & 8 & 9 & 50 & 72 & 7 & $\mathrm{~N}$ & Gauss \\
\hline \multicolumn{10}{|c|}{ Means } \\
\hline Mean of all normal polarity units & & 8 & & 2 & 66 & 24 & 26 & & \\
\hline $\begin{array}{l}\text { Mean of all reversed polarity } \\
\text { units }\end{array}$ & & 3 & & 172 & -49 & 23 & 26 & & \\
\hline $\begin{array}{l}\text { Mean of all normal and reversed } \\
\text { units }\end{array}$ & & 11 & & 358 & 61 & 9 & 17 & & \\
\hline
\end{tabular}

\subsubsection{Record of the First Laurentide Glaciation}

The arrival of the first Laurentide glacier into south-central and southern Saskatchewan is documented at the Sutherland Overpass and Wascana Creek sites by the presence of a reversely magnetized till (Mennon Fm) at the base of the Pleistocene sequence. The Mennon Fm is assigned to the latest Matuyama Reversed Chron, and more precisely to MIS $20(\sim 0.83-\sim 0.80 \mathrm{Ma})$, based on its polarity, the age of underlying preglacial deposits, and the age of the overlying Wascana Creek tephra (Figs. 2 and 9). 


\subsubsection{Record of Subsequent Laurentide Glaciations}

Overlying the deposits of the first Laurentide glaciation at both sites is the lower unit of the Dundurn Fm which is normally magnetized, and is assigned to the Brunhes Normal Chron. It in turn is overlain by the upper unit of the Dundurn Fm which contains the Wascana Creek tephra $(0.639 \pm 0.002 \mathrm{Ma})$, is normally magnetized, and based on the

\section{a)}

$$
\begin{aligned}
& \text { Upper hemisphere } \\
& \text { - Lower hemispehre } \\
& \text { d.95 }
\end{aligned}
$$

Sutherland Borecore

1. U. Floral Fm.

2. L. Floral Fm.

3. Warman Fm

4. Dundurn Fm. (up. unit)

5. Dundurn Fm. (Iwr. unit)

6. Mennon Fm.

7. Empress Gp. (unn. unit)

Wascana Creek Outcrop \& Borecore

8. Dundurn Fm (up. unit-outcrop)

9. Mennon Fm (borecore)

10. Empress Gp. (Stewart V. unit, borecore)

11. Empress Gp. (unnamed unit, borecore)



b)

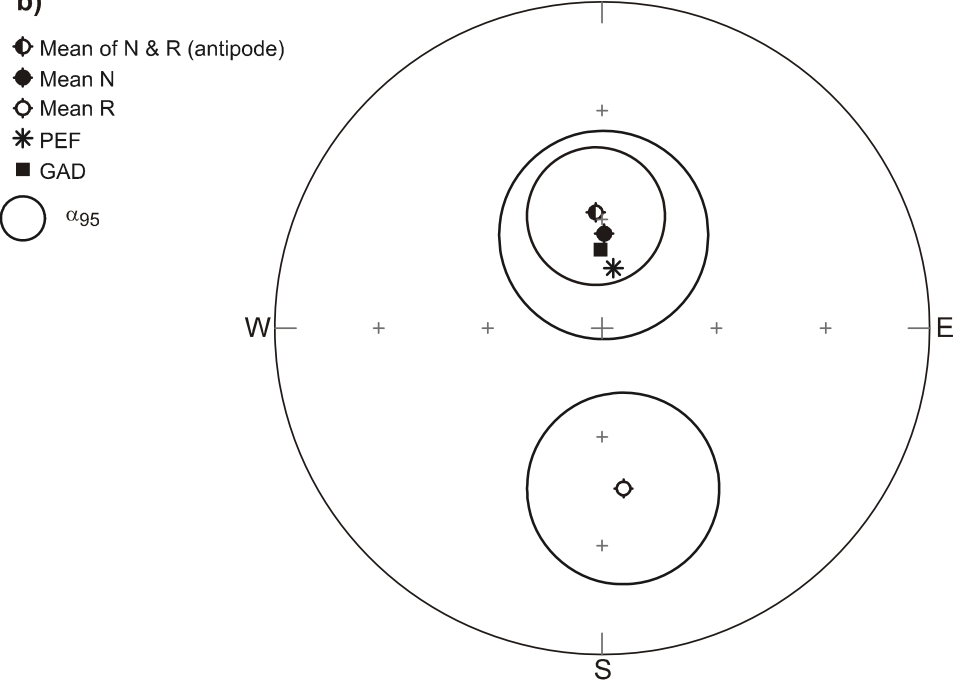

Fig. 8 a) Stereographic plots of unit means and their 95\% confidence intervals for both sampling sites. Units 1 and 2 in the Sutherland Borecore (Upper and Lower Floral Formations) exhibit westerly and easterly declinations respectively, probably as a result of core rotation during the extraction process. b) Stereographic plots of the mean normal $(\mathrm{N})$, mean reversed (R), and overall mean (N\&R), and their associated 95\% confidence intervals. 


\section{R.W. Barendregt et al.}

tephra age and polarity, can be reliably assigned to MIS 16 (0.68-0.62 Ma). The remainder of the formations at both sites are normally magnetized and fall within the mid to late Brunhes Normal Chron. They are assigned to marine oxygen isotope stages (Fig. 9) based on stratigraphic sequences, and age estimates provided from interglacial deposits (Skwara Woolf, 1981; David, 1966, 1987).

\section{DISCUSSION}

The number of glaciations documented across the Canadian Prairies (Barendregt, 2011; Barendregt and Irving, 1998) ranges from a single (Late Wisconsin) glaciation near the all time limit of Laurentide ice in Alberta (1500-800 m elevation), to at least two glaciations in areas between $\sim 800-650 \mathrm{~m}$ elevation (Alberta-Saskatchewan border region), and increases to seven (Figs. 2 and 9) in south-central Saskatchewan $(<650 \mathrm{~m})$. Of these glaciations, six fall within the Brunhes Normal Chron (late Wisconsin, two Illinoian, and three pre-Illinoian glaciations). The three pre-Illinoian glaciations (tills) in Saskatchewan include the Mennon Fm (MIS 20), lower unit of the Dundurn Fm (MIS 18?), and the upper unit of the Dundurn Fm (MIS 16). The lower and upper units of the Dundurn Fm are separated by an unconformity marked by extensive thicknesses of nonglacial sands and gravels (Fig. 3) in places containing an extensive weathering zone, suggesting that the upper and lower units of the Dundurn Fm represent two separate glaciations. The upper unit of the Dundurn Fm contains the Wascana Creek Tephra $(0.639 \pm 0.002 \mathrm{Ma})$ and can be reliably assigned to MIS 16 . It is therefore likely that the lower unit of the Dundurn Fm was deposited by an older (MIS 18?) glaciation. The underlying Mennon Fm till was deposited during (MIS 20).

It would appear that the earliest pre-Illinoian glaciation (Mennon Fm) may have reached its maximum southerly extent near Regina, Saskatchewan, as only normally magnetized tills have been reported to the south of Regina, in the Wellsch Valley area, and in Montana and North Dakota (Fig. 1).

The polarity record established from glacial and interglacial sediments in southern and south-central Saskatchewan spans about 1.0 Ma. For much of the Pleistocene, sediment deposition was intermittent, occurring predominantly during periods of deglaciation. At least seven glaciations are recorded from stratigraphically distinct till units (Christiansen, 1968, 1992), while four interglaciations (Figs. 3 and 9) are documented by nonglacial sands and gravels and a weathering zone between the lower and upper units of the Dundurn, by the Wascana Creek Tephra beds, the Prelate Paleosol (David, 1966, 1987), and the Riddell member of the Floral Fm (Skara Woolf, 1981).

A paleomagnetic record of glacial deposits from the American Midwest (Roy et al., 2004 ) provides evidence for 7 pre-Illinoian ( $>$ MIS 6) tills of which two groups (4 tills) are reversely magnetized, and 1 group ( 3 tills) is normally magnetized. Clearly the glacial record in the American Midwest appears to be more extensive than that of southern Saskatchewan, and this may be due to erosion of some of the glacial records in the study area, or more likely, relates to different ice sources for some of the Midwestern tills. 




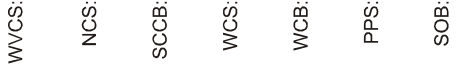

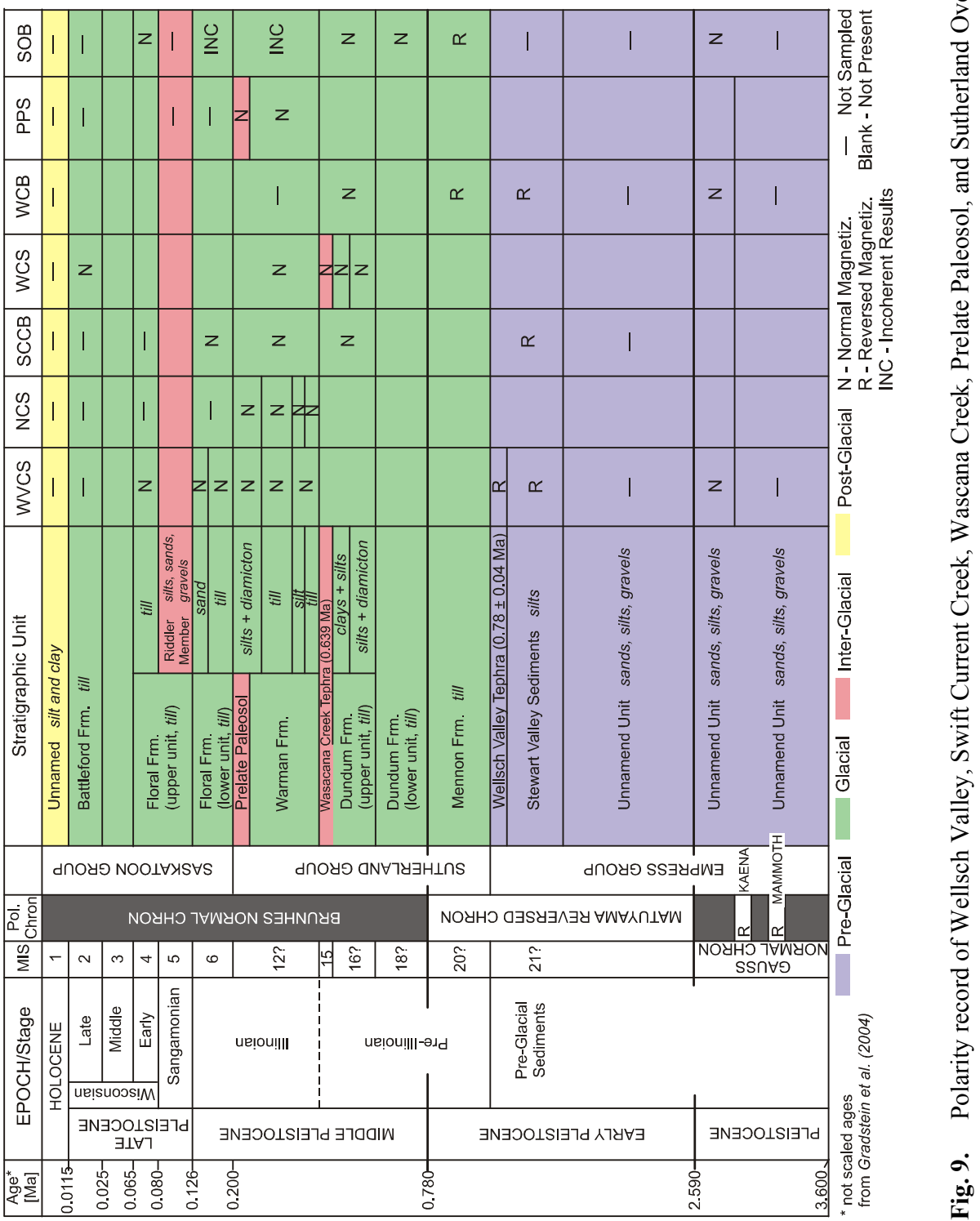




\section{R.W. Barendregt et al.}

\section{CONCLUSIONS}

The borecore sampling procedure described here provides a relatively inexpensive means of collecting oriented samples for paleomagnetic analysis, in areas where outcrops are poorly exposed or non-existent. While paleomagnetic directions may be affected by rotation during extrusion of the core, or by compaction, results reported here suggest that reliable polarity data can be obtained. Glacial tills are generally noisy recorders of the earth's paleofield, and therefore a larger percentage of samples produced incoherent results. This problem can be addressed by collecting greater numbers of samples from till units. The magnetostratigraphic records from the Sutherland Overpass and Wascana Creek sites provide the first evidence of reversely magnetized glacial deposits on the Canadian Prairies. These deposits are assigned to the latest Matuyama (MIS 20) and indicate that Laurentide (continental) glaciations did not impact southern Saskatchewan until the late Early Pleistocene. The first Laurentide ice appears to have been at its maximum extent in the Regina area, and it is therefore unlikely that early Pleistocene Laurentide glaciations (MIS $\geq 20$ ) reached areas to the south and west of the study sites.

Acknowledgements: Saskatchewan Highways and Transportation, through the efforts of R.A. Widger, provided drilling and geophysical logging as part of an ongoing cooperative research program with the University of Saskatchewan. E.A. Christiansen provided regional stratigraphic data which was used in the magnetostratigraphic correlation. Boreholes were drilled by M. Minchuk and Y. Morin, and L. Sinclair collected samples, operated the geophysical logging equipment, compiled the records for each site, and supervised the drilling projects. Paleomagnetic measurements were made by J. Baker, A. Anwar and G. Rathwell at the Geological Survey of Canada, Pacific, Sidney, British Columbia, under supervision of R. Enkin. We thank D. Kent and an anonymous reviewer for reviewing the manuscript, and providing helpful comments. The project was funded by Natural Sciences and Engineering Research Council of Canada grant 0581 to R.W. Barendregt.

\section{References}

Barendregt R.W., 2010. Magnetostratigraphy of Quaternary sections in Eastern Alberta, Saskatchewan, and Manitoba. Travaux Géophysiques, XXXIX, 5.

Barendregt R.W., 2011. Magnetostratigraphy of Quaternary sections in Eastern Alberta, Saskatchewan and Manitoba. In: Ehlers J., Gibbard P.L. and Hughes P.D. (Eds), Quaternary Glaciations - Extent and Chronology: A Closer Look. Elsevier, Amsterdam, The Netherlands, 591-600.

Barendregt R.W. and Duk-Rodkin A., 2011. Chronology and extent of late Cenozoic ice sheets in North America: A magnetostratigraphic assessment. In: Ehlers J., Gibbard P.L. and Hughes P.D. (Eds), Quaternary Glaciations - Extent and Chronology: A Closer Look. Elsevier, Amsterdam, The Netherlands, 419-426.

Barendregt R.W., Duk-Rodkin A., Enkin R.E., Baker J., Christiansen E., Naeser N.D. and Westgate J., 2007. New magnetostratigraphic data from central Saskatchewan and from the Horton Plateau, Mackenzie District, NWT: evidence for Matuyama Chron glaciations in the Interior Plains of Canada. Abstract, XVII INQUA Congress, Cairns, Australia, 28 July-3 August, 2007 (http://www.icms.com.au/inqua2007/abstract/1361.htm). 
Barendregt R.W. and Irving E., 1998. Changes in the extent of North American ice sheets during the late Cenozoic. Can. J. Earth Sci., 35, 504-509.

Barendregt R.W., Irving E., Christiansen E.A., Sauer E.K. and Schreiner B.T., 1998. Stratigraphy and paleomagnetism of Late Pliocene and Pleistocene sediments from Wellsch Valley and Swift Current Creek areas, southwestern Saskatchewan, Canada. Can. J. Earth Sci., 35, $1347-1361$.

Barendregt R.W., Thomas F.F., Irving E., Baker J., Stalker A.M. and Churcher C.S., 1991. Stratigraphy and paleomagnetism of the Jaw Face section, Wellsch Valley site, Saskatchewan. Can. J. Earth Sci., 28, 1353-1364.

Cande S.C. and Kent D.V., 1995. Revised calibration of the geomagnetic timescale for the Late Cretaceous and Cenozoic. J. Geophys. Res., 100(B4), 6093-6095.

Christiansen E.A., 1968. Pleistocene stratigraphy of the Saskatoon area, Saskatachewan, Canada. Can. J. Earth Sci., 5, 1167-1173.

Christiansen E.A., 1992. Pleistocene stratigraphy of the Saskatoon area, Saskatchewan, Canada: an update. Can. J. Earth Sci., 29, 1767-1778.

David P.P., 1966. The Late-Wisconsin prelate ferry paleosol of Saskatchewan. Can. J. Earth Sci., 3, 685-696.

David P.P., 1987. The Prelate Ferry Paleosol: a new date. GAC-MAC 1987 Saskatoon: Joint Annual Meeting, May 25-27, 1987, University of Saskatchewan. Volume 12 of Abstracts of Papers, Geological Association of Canada Meeting. Dept. of Geological Sciences, University of Saskatchewan, 36.

Gibbard P.L., Head M.J., Walker M.J.C. and the Subcommission on Quaternary Stratigraphy, 2010. Formal ratification of the Quaternary System/Period and the Pleistocene Series/Epoch with a base at 2.58 Ma. J. Quat. Sci., 25, 96-102.

Kirschvink J.L. 1980. The least-squares line and plane and the analysis of paleomagnetic data. Geophys. J. Roy. Astr. Soc., 62, 699-718.

Lanphere M.A., Champion D.E., Christiansen R.L., Izett G.A. and Obradovich J.D., 2002. Revised age for tuffs of the Yellowstone Plateau volcanic field - assignment of the Huckleberry Ridge Tuff to a new geomagnetic polarity event. Geol. Soc. Am. Bull., 114, 559-568.

Lisiecki L.E. and Raymo M., 2005. A Pliocene-Pleistocene stack of 57 globally distributed benthic $\delta^{18}$ O records. Paleoceanography, 20, PA1003. DOI:10.1029/2004PA001071.

Raymo M.E., 1992. Global climate change: a three million year perspective. In: Kukla G.K. and Went E. (Eds.), Start of a Glacial. NATO ASI Series, Series I, Global Environmental Change, 3, 207-223.

Raymo M.E., Ruddiman W.F., Backman J., Clement B.M. and Martinson D.G., 1989. Late Pliocene variation in Northern Hemisphere ice sheets and North Atlantic Deep Water Circulation. Paleoceanography, 4, 413-446.

Roy M., Clark P.U., Barendregt R.W., Glasmann J.R. and Enkin R.J., 2004. Glacial stratigraphy and paleomagnetism of late Cenzoic deposits of the north-central United States. Geol. Soc. Am. Bull., 116, 30-41.

Ruddiman W.F., Raymo M.E., Martinson D.G., Clement B.M. and Backman J., 1989. Pleistocene evolution of Northern Hemisphere climate. Paleoceanography, 4, 353-412. 


\section{R.W. Barendregt et al.}

Ruddiman W.F., Raymo M.E. and McIntyre A., 1986. Matuyama 41,000-year cycles; North Atlantic Ocean and northern hemisphere ice sheets. Earth Planet. Sci. Lett., 80, 117-129.

Shackleton N.J., Hall M.A. and Pate D., 1995. Pliocene stable isotope stratigraphy of site 846. Proceedings of the Ocean Drilling Program: Scientific Results, 138, 337-353.

Skwara Woolf T. 1981. Biostratigraphy and paleoecology of Pleistocene deposits (Riddell Member, Floral Formation, Late Rancholabrean), Saskatoon, Canada. Can. J. Earth Sci., 18, 311-322.

Westgate J.A., Christensen E.A. and Boellstorff J.D., 1977. Wascana Creek Ash (Middle Pleistocene) in southern Saskatchewan: characterization, source, fission track age, paleomagnetism and stratigraphic significance. Can. J. Earth Sci., 14, 357-374. 